No. 1

5 Preface

Ronco, C. (Vicenza); Levin, N.W. (New York, N.Y.)

6 Hyperphosphatemia in Renal Failure Ritz, E.; Gross, M.-L. (Heidelberg)

10 Renal Advances in Ultrasound Elasticity Imaging: Measuring the Compliance of Arteries and Kidneys in End-Stage Renal Disease Weitzel, W.F.; Kim, K.; Rubin, J.M.; Xie, H.; O’Donnell, M. (Ann Arbor, Mich.)

18 Home Hemodialysis and Remote Monitoring: Current Technology, Requirements and Capabilities Schlaeper, C.; Diaz-Buxo, J.A. (Lexington, Mass.)

23 Saving Infected Catheters: Why and How Allon, M. (Birmingham, Ala.)

29 Novel Therapies for Hemodialysis Vascular Access Dysfunction: Fact or Fiction!

Roy-Chaudhury, P.; Kelly, B.S.; Melhem, M.; Zhang, J.; Li, J.; Desai, P.; Munda, R.; Heffelfinger, S.C. (Cincinnati, Ohio)

36 Vascular Access Monitoring: Methods and Procedures Something to Standardize?

Lopot, F.; Nejedlý, B.; Válek, M. (Prague-Strahov)

45 Vascular Access Monitoring Improves Outcomes Sands, J.J. (Celebration, Fla.)

50 Access Monitoring Does Not Really Improve Outcomes Paulson, W.D. (Augusta, Ga.)

57 Reverse Epidemiology: A Spurious Hypothesis or a Hardcore Reality?

Kalantar-Zadeh, K., Kilpatrick, R.D.; Kuwae, N.; Wu, D.Y. (Torrance, Calif.)

64 Inflammation and Vascular Calcification Moe, S.M.; Chen, N.X. (Indianapolis, Ind.)

72 C-Reactive Protein in End-Stage Renal Disease: Are There Reasons to Measure It? Stenvinkel, P.; Lindholm, B. (Stockholm)

79 Effect of Daily Hemodialysis on Monocytes Apoptosis Andrikos, E. (Ioannina); Buoncristiani, E. (Perugia); D’Intini, V.; Bordoni, V.; Bonello, M. (Vicenza); Levin, N. (New York, N.Y.); Buoncristiani, U. (Perugia); Pappas, M. (Ioannina); Ronco, C. (Vicenza)

83 Phosphate Kinetics during Different Dialysis Modalities Ratanarat, R.; Brendolan, A.; Volker, G.; Bonello, M.; Salvatori, G.; Andrikos, E.; Yavuz, A.; Crepaldi, C.; Ronco, C. (Vicenza)

91 Absence of NF- $\kappa$ B Activation by a New Polystyrene-Type Adsorbent Designed for Hemoperfusion

Menegatti, E (Torino); Ronco, C. (Vicenza); Winchester, J.F.

(New York, N.Y.); Dragonetti, A.; Di Simone, D.; Davit, A.; Mengozzi, G.; Marietti, G.; Loduca, G.; Mansouri, M.; Sancipriano, G.P.; Sena, L.M.; Roccatello, D. (Torino)

99 Author Index

100 Subject Index
No. 2

Original Papers

101 A Prospective, Randomized, Double-Blind Crossover Study on the Use of $5 \%$ Citrate Lock versus $10 \%$ Citrate Lock in Permanent Hemodialysis Catheters

Meeus, G.; Kuypers, D.R.J.; Claes, K.; Evenepoel, P.; Maes, B.; Vanrenterghem, Y. (Leuven)

106 Influence of Hepatitis C Virus Infection on Soluble Cellular Adhesion Molecules in Hemodialysis Patients

Peng, Y.-S.; Chiang, C.-K.; Hsu, S.-P.; Pai, M.-F.; Hung, K.-Y.; Kao, J.-H. (Taipei)

113 Intracranial Pressure Monitoring in Patients with Fulminant Hepatic Failure Treated with Plasma Exchange and Continuous Hemodiafiltration

Nakanishi, K.; Hirasawa, H.; Oda, S.; Shiga, H.; Matsuda, K.;

Nakamura, M.; Hirano, T.; Hirayama, Y.; Moriguchi, T.; Watanabe, E.; Nitta, M. (Chuo)

119 Mixed Bacterial Infection Model of Sepsis in Rabbits and Its Application to Evaluate Superantigen-Adsorbing Device Fukuyama, M.; Miwa, K.; Shibayama, N. (Shiga); Ogura, S.; Nishiyama, T.; Maekawa, N. (Kagawa)

128 Association of the $-159 \mathrm{C} / \mathrm{T}$ Polymorphism of the Endotoxin Receptor (CD14) with Carotid Artery Disease and Cardiovascular Mortality in Dialysis Patients Losito, A. (Perugia); Kalidas, K. (London); Santoni, S.; Errico, R. (Perugia); Jeffery, S. (London)

134 Low-Density Lipoprotein Cholesterol: Association with Mortality and Hospitalization in Hemodialysis Patients Chiang, C.-K.; Ho, T.-I.; Hsu, S.-P.; Peng, Y.-S.; Pai, M.-F.; Yang, S.-Y.; Hung, K.-Y.; Tsai, T.-J. (Taipei)

144 Plasma Interleukin-18 Levels in Chronic Renal Failure and Continuous Ambulatory Peritoneal Dialysis Chiang, C.-K.; Hsu, S.-P.; Pai, M.-F.; Peng, Y.-S.; Ho, T.-I; Liu, S.-H.; Hung, K.-Y.; Tsai, T.-J.; Hsieh, B.-S. (Taipei)

Short Communication

141 Effect of Plasmapheresis on Serum Beta-Endorphin Levels Bender, T.; Polner, K.; Barna, I.; Géher, P.; Bőke, M.; Haris, A. (Budapest)

Abstracts

149 The 10th International Conference on Continuous Renal Replacement Therapies (CRRT).

March 10-12, 2005, San Diego, Calif.

Editor: R.L. Mehta, San Diego, Calif. (Available online only)
KARGER

Fax +4161306 1234 E-Mail karger@karger.ch www.karger.com
(C) 2005 S. Karger AG, Basel

Access to full text and tables of contents, including tentative ones for forthcoming issues: www.karger.com/bpu issues 
No. 3

Editorial Review

203 Why Do Dialysis Patients Develop a Heart of Stone and Bone of China?

Martola, L.; Barany, P.; Stenvinkel, P. (Stockholm)

Original Papers

175 Filter Run Time in CVVH: Pre- versus Post-Dilution and Nadroparin versus Regional Heparin-Protamine Anticoagulation

van der Voort, P.H.J.; Gerritsen, R.T.; Kuiper, M.A.; Egbers, P.H.M.; Kingma, W.P.; Boerma, E.C. (Leeuwarden)

181 Detection of Fluorescently Labeled Microparticles in Blood Brandl, M.; Hartmann, J.; Posnicek, T. (Krems); Ausenegg, F.R.; Leitner, A. (Krems/Graz); Falkenhagen, D. (Krems)

190 Endothelin-1 Levels and Conduit Artery Mechanical Properties in End-Stage Renal Disease

Dammers, R.; Hoeks, A.P.G.; Tordoir, J.H.M. (Maastricht); Welten, R.J.Th.J. (Heerlen); Hamulyák, K.; Kooman, J.P.; Kitslaar, P.J.E.H.M. (Maastricht)

196 Biocompatibility Parameters of Different Dialysis Membranes Assessed during Systemic Inflammation

Gueler, F.; Gwinner, W.; Schiborr, C.; Martin, M.; Klos, A.; Kirsch, T.; Fiebeler, A.; Haller, H.; Fliser, D. (Hannover)

211 Membrane Biocompatibility Does Not Affect Whole Body Protein Metabolism during Dialysis

Veeneman, J.M.; Kingma, H.A.; Stellaard, F.; de Jong, P.E.; Reijngoud, D.-J.; Huisman, R.M. (Groningen)

219 Does Glucose Present in the Dialysate Limit Oxidative Stress in Patients Undergoing Regular Hemodialysis?

Bober, J.; Kwiatkowska, E.; Kedzierska, K.; Olszewska, M.; Dolegowska, B.; Domanski, L.; Herdzik, E.; Ciechanowski, K.; Chlubek, D. (Szczecin)

Abstracts

227 4th International Congress of the Vascular Access Society (VAS). May 25-27, 2005, Berlin, Germany

Editor: V. Mickley (Baden-Baden)

\section{No. 4}

Original Papers

263 Pulsatile Flow Improves Renal Function in High-Risk Cardiac Operations

Kocakulak, M.; Aşkin, G.; Küçükaksu, S.; Tarcan, O.; Pişkin, E. (Ankara)

275 Role of Interleukin-1及 in the Development of Malnutrition in Chronic Renal Failure Patients

Maruyama, Y.; Stenvinkel, P.; Lindholm, B. (Stockholm)

282 Particle Leakage in Extracorporeal Blood Purification Systems Based on Microparticle Suspensions

Hartmann, J.; Schildboeck, C.; Brandl, M.; Falkenhagen, D. (Krems)

287 Assessment of the Stability of an Immunoadsorbent for the Extracorporeal Removal of Beta-2-Microglobulin from Blood Daniels, C.M.; Woolverton, E.M. (Evanston, Ill.); Sprague, S.M. (Chicago, Ill./Evanston, Ill.); Ameer, G.A. (Evanston, Ill.)

298 The Prometheus ${ }^{\circledR}$ Device for Extracorporeal Support of Combined Liver and Renal Failure

Rifai, K.; Ernst, T.; Kretschmer, U.; Hafer, C.; Haller, H.; Manns, M.P.; Fliser, D. (Hannover)

303 Benefit of Glucose-Free Dialysis Solutions on Glucose and Lipid Metabolism in Peritoneal Dialysis Patients

Martikainen, T.; Teppo, A.-M.; Grönhagen-Riska, C.; Ekstrand, A. (Helsinki)

311 Ultrapure Dialysate Reduces Plasma Levels of $\boldsymbol{\beta}_{2}$-Microglobulin and Pentosidine in Hemodialysis Patients Furuya, R. (Iwata); Kumagai, H. (Shizuoka); Takahashi, M. (Hamamatsu); Sano, K. (Iwata); Hishida, A. (Hamamatsu)
317 Systemic Nitric Oxide Production Rate during Hemodialysis and Its Relationship with Nitric Oxide-Related Factors

Mochizuki, S.; Ono, J.; Yada, T.; Ogasawara, Y. (Kurashiki); Miyasaka, T. (Okayama); Kimoto, M. (Soja); Kashihara, N. (Kurashiki); Kajiya, F. (Okayama)

325 Prostacyclin versus Citrate in Continuous Haemodiafiltration: An Observational Study in Patients with High Risk of Bleeding Balik, M.; Waldauf, P.; Plášil, P.; Pachl, J. (Prague)

330 Diabetic Patients Can Do as Well on Peritoneal Dialysis as Nondiabetic Patients

Tang, W.; Cheng, L.-T.; Wang, T. (Beijing)

Letters to the Editor

268 Origin of Nocturnal Home Haemodialysis

Shaldon, S. (Monte Carlo)

338 Pre- versus Post-Dilution CVVH

Ricci, Z. (Rome); Ronco, C. (Vincenza)

Perspectives

269 The Human Nephron Filter: Toward a Continuously Functioning, Implantable Artificial Nephron System Nissenson, A.R. (Los Angeles, Calif.); Ronco, C. (Vicenza); Pergamit, G.; Edelstein, M.; Watts, R. (Burlingame, Calif.)

No. 5

Original Papers

339 A New Procedure Allowing the Complete Removal and Prevention of Hemodialysis Biofilms

Marion, K. (Lyon); Pasmore, M. (Bozeman, Mont.); Freney, J.; Delawari, E.; Renaud, F. (Lyon); Costerton, J.W. (Bozeman, Mont.); Traeger, J. (Lyon)

349 Detoxifying Capacity and Kinetics of Prometheus ${ }^{\circledR}$ - A New Extracorporeal System for the Treatment of Liver Failure Evenepoel, P.; Laleman, W.; Wilmer, A.; Claes, K.; Maes, B.; Kuypers, D. Bammens, B.; Nevens, F.; Vanrenterghem, Y. (Leuven)

359 Role of the Dialyzer Membrane on the Overall Phosphate Kinetics during Hemodialysis

Katopodis, K.P.; Chala, A.; Koliousi, E.; Takouli, L.; Kalaitzidis, R.; Theodorou, J.; Siamopoulos, K.C. (Ioannina)

365 Does Bicarbonate Transfer Have Relevant Hemodynamic Consequences in Standard Hemodialysis?

Gabutti, L.; Ross, V.; Duchini, F.; Mombelli, G. (Locarno); Marone, C. (Bellinzona)

373 Volume Status and Blood Pressure in Continuous Ambulatory Peritoneal Dialysis Patients

Wang, X. (Beijing/Stockholm); Axelsson, J.; Lindholm, B. (Stockholm); Wang, T. (Beijing)

379 Effect of Oral Sodium Bicarbonate Supplementation on Interdialytic Weight Gain, Plasma Sodium Concentrations and Predialysis Blood Pressure in Hemodialysis Patients.

A Cross-Sectional and Interventional Study

Movilli, E.; Gaggia, P.; Camerini, C.; Brunori, G.; Vizzardi, V.; Cancarini, G. (Brescia)

384 Interleukin-1 Gene Cluster Polymorphisms Are Associated with Nutritional Status and Inflammation in Patients with End-Stage Renal Disease

Maruyama, Y.; Nordfors, L.; Stenvinkel, P.; Heimbürger, O.; Bárány, P.; Pecoits-Filho, R.; Axelsson, J. (Stockholm); Hoff, C.M.; Holmes, C.J.

(McGaw Park, Ill.); Schalling, M.; Lindholm, B. (Stockholm)

Abstracts

395 23th Annual Meeting of the International Society of Blood Purification (ISBP)

August 31-September 2, 2005, Rotterdam

Editor: Robert Zietse (Rotterdam)

414 Author Index 


\section{No. 6}

Editorial

429 Atrial Natriuretic Peptide: A Regulator of Transvascular Fluid Transport in Dialysis?

Zietse, R. (Rotterdam)

Original Papers

417 Changes in Plasma Interleukin-18 by Direct Hemoperfusion with Polymyxin B-Immobilized Fiber in Patients with Septic Shock

Nakamura, T.; Kawagoe, Y.; Suzuki, T. (Chiba); Shoji, H. (Tokyo); Ueda, Y. (Saitama); Kobayashi, N.; Koide, H. (Tokyo)

421 Resistin Serum Levels Are Increased but Not Correlated with Insulin Resistance in Chronic Hemodialysis Patients

Filippidis, G.; Liakopoulos, V. (Larissa); Mertens, P.R. (Aachen); Kiropoulos, T.; Stakias, N.; Verikouki, C.; Patsidis, E.; Koukoulis, G.; Stefanidis, I. (Larissa)

431 Relationship between Filtration Coefficients of Microvasculature and Levels of Atrial Natriuretic Peptide or Echocardiographic Measurements

Yashiro, M.; Watanabe, H.; Tomita, M.; Yamadori, N. (Kyoto); Muso, E. (Osaka)

440 Plasma Exchange Using a Continuous Venovenous Hemofiltration Machine in Children Ciechanska, E.; Segal, L.; Wong, H.; Chretien, C.; Feber, J.; Filler, G. (Ottawa)

450 Impact of a Genetic Polymorphism of the Interleukin-1 Receptor Antagonist on Technique Survival in Peritoneal Dialysis Patients

Uchiyama, K.; Naito, K.; Tsuchida, M.; Takai, K.; Okayama, N.; Fujimura, K.; Hinoda, Y. (Yamaguchi)
459 Metabolic Acidosis in Peritoneal Dialysis Patients: The Role of Residual Renal Function

Tian, X.; Shan, Y.; Zhe, X.; Cheng, L.; Wang, T. (Beijing)

466 Assessment of Coronary Artery Disease in Hemodialysis Patients with Delayed Systolic Blood Pressure Response after Exercise Testing

Fukui, M. (Osaka); Mori, Y. (Kyoto); Takehana, K.; Masaki, H.; Motohiro, M. Sakamoto, N.; Kitamura, T.; Yoshida, S. (Osaka); Nakamura, S.; Baden, M. (Hyogo); Nishikawa, M.; Iwasaka, T. (Osaka)

473 Regional Citrate Anticoagulation during Hemodialysis. A Simplified Procedure Using Duocart Biofiltration Ridel, C.; Mercadal, L. (Paris); Béné, B. (Lyon); Hamani, A.; Deray, G.; Petitclerc, T. (Paris)

Case Report

446 Unusual Complication of Central Venous Catheter in Hemodialysis

Di Iorio, B.R.; Mondillo, F.; Bortone, S.; Nargi, P.; Capozzi, M.; Spagnuolo, T.; Cucciniello, E.; Bellizzi, V. (Solofra)

481 Author Index Vol. 23, 2005

483 Subject Index Vol. 23, 2005

Suppl. 1

Accumulation of Metals and Minerals in Chronic Kidney Disease

Guest Editor: Isidro B. Salusky (Los Angeles, Calif.)
S. Karger

Medical and Scientific Publishers Basel $\bullet$ Freiburg $\bullet$ Paris $\bullet$ London New York $\bullet$ Bangalore $\bullet$ Bangkok Singapore $\cdot$ Tokyo $\cdot$ Sydney
Disclaimer

The statements, options and data contained in this publication are solely those of the individual authors and contributors and not of the publisher and the editor(s). The appearance of advertisements in the journal is not a warranty, endorsement, or approval of the products or services advertised or of thei effectiveness, quality or safety. The publisher and the editor(s) disclaim responsibility for any injury to persons or property resulting from any ideas, methods, instructions or products referred to in the content or advertisements.

Drug Dosage

The authors and the publisher have exerted every effort to ensure that drug selection and dosage set forth in this text are in accord with current recommendations and practice at the time of publication. However, in view of ongoing research, changes in government regulations, and the constant flow of information relating to drug therapy and drug reactions, the reader is urged to check the package insert for each drug for any change in indications and dosage and for added warnings and precautions. This is particularly important when the recommended agent is a new and/or infrequently employed drug.
All rights reserved.

No part of this publication may be translated into other languages, reproduced or utilized in any form or by any means, electronic or mechanical, including photocopying recording, microcopying, or by any information storage and retrieval system, without permission in writing from the publisher or, in the case of photocopying, direct payment of a specified fee to the Copyright Clearance Center (see 'General Information')

(c) Copyright 2005 by S. Karger AG,

P.O. Box, CH-4009 Basel (Switzerland)

Printed in Switzerland on acid-free paper by

Reinhardt Druck, Base 